\title{
CAN INSTITUTIONAL FORCES CREATE COMPETITIVE ADVANTAGE? EMPIRICAL EXAMINATION OF ENVIRONMENTAL INNOVATION
}

\author{
Pascual Berrone \\ Liliana Gelabert \\ Andrea Fosfuri \\ Luis R. Gómez-Mejía
}




\title{
CAN INSTITUTIONAL FORCES CREATE COMPETITIVE ADVANTAGE? EMPIRICAL EXAMINATION OF ENVIRONMENTAL INNOVATION
}

\author{
Pascual Berrone ${ }^{1}$ \\ Liliana Gelabert ${ }^{2}$ \\ Andrea Fosfuri ${ }^{2}$ \\ Luis R. Gómez-Mejía ${ }^{3}$
}

\begin{abstract}
We examine institutional pressures as antecedents of environmental innovation. Drawing on institutional theory and a resourced-based view of the company, we argue that regulatory and normative forces influence the companies' propensity to innovate in environmental-related projects. Furthermore, we suggest that this relationship is contingent on the availability and specificity of the companies' resources. These relationships were tested using environmental patents and citations of 340 publicly-traded companies from polluting industries in the U.S. Results suggest that institutional pressures can be a source of competitive advantage, and regulatory forces are becoming more strongly associated with environmental innovations as the intensity of companies' R\&D activities increase.
\end{abstract}

\footnotetext{
${ }^{1}$ Professor, Strategic Management, IESE

2 Professor, Universidad Carlos III de Madrid

${ }^{3}$ Professor, Arizona State University
}

Keywords: environmental innovation, institutional theory, resource-based view. 


\section{CAN INSTITUTIONAL FORCES CREATE COMPETITIVE ADVANTAGE? EMPIRICAL EXAMINATION OF ENVIRONMENTAL INNOVATION}

\section{Introduction}

A central tenet of institutional theory (DiMaggio and Powell, 1983; Meyer and Rowan, 1977; Scott, 1995) suggests that institutional pressures lead organizations to adopt similar structures, strategies, and processes. That is, external forces work to make companies more alike - what institutional literature calls "organizational isomorphism" (DiMaggio and Powell, 1983). Government, industrial associations, and other social actors define actions deemed acceptable and exert pressures on companies for conformity. In order to reduce environmental uncertainty and conform to social expectations, companies imitate practices used by other organizations (DiMaggio and Powell, 1983; Haveman, 1993). In turn, companies gain social support as legitimacy is endorsed by institutional actors (Deephouse, 1996; DiMaggio and Powell, 1983). According to this perspective, companies adopt similar practices to avoid the pitfalls of newness (Aldrich and Fiol, 1994; Singh, Tucker, and House, 1984). Consequently, innovation may be a harmful strategy for companies because, by challenging standard practices, they jeopardize their legitimacy. In the words of Deephouse (1996, p. 1026), "organizations that innovate or have unique strategies suffer in terms of legitimacy - such behaviors is questioned or even deemed unacceptable by external actors”. Paradoxically, however, it has also been suggested that organizational legitimacy is actually a key factor that enables companies to innovate. Under the rubric of institutional theory and resource dependence theory, Sherer and Lee (2002) argued that legitimate organizations are likely to create and experiment with new technical rationales that differ from current standards precisely because they have the high status to be different. This apparent contradiction suggests that important gaps in our understanding of the relationships between institutional pressures, innovation, and legitimacy still remain. Especially noteworthy is that there has been little consideration of how external forces may contribute to technological innovation.

Using polluting industries as the setting for our study, we explore these relationships by drawing on insights from institutional theory and a resource-based view of the company (hereafter referred to as "RBV"). We propose a hybrid framework to argue that regulatory forces (i.e., those emanating from governments) and normative forces (i.e., those stemming from the industry) towards environmental concerns demand unique responses and generate business opportunities that prompt environmental-related innovations. We further suggest that companies are more likely to respond innovatively to institutional pressures when they possess 
resources and these resources are specific. We test our theoretical arguments using longitudinal data (1997-2001) of 120 publicly traded companies from polluting industries in the U.S. Overall, our results support our general contention.

Our work makes important contributions to current literature. First, by combining insights from institutional theory and RBV, we strengthen the explanatory power of both. We broaden institutional theory by offering an alternative logic to the traditional institutional prediction that suggests external forces work towards isomorphism. We investigate the extent to which external forces can actually generate unique and inimitable internal capabilities, and how this relationship is affected by a company's resources. In tandem, we enhance RBV by including contextual factors in the development of organizational capabilities. Our study suggests that innovation can result not only in economic gains but also a response to societal expectations. Therefore, our combined framework allows us to uncover the missing link between institutional pressures, innovation, and organizational legitimacy. Second, while links between companylevel factors and innovative actions have drawn significant attention of scholars (Balkin, Markman, and Gómez-Mejía, 2000; Wu, 2007), contextual aspects and their influence on innovation have been only obliquely studied. Thus, our study contributes to innovation literature by analyzing how institutional factors affect the company's propensity to innovate. Third, we enlarge environmental management literature by bringing together two theories extensively used in the field. By doing so, we offer a more holistic view that provides a solid platform for understanding the antecedents of environmental innovation. We also contribute empirically to this field by approaching environmental innovation through patent activity (i.e., patent count and citations). In previous studies, environmental innovation has been commonly measured through questionnaire surveys (Anton, Deltas, and Khanna, 2004; Christmann, 2000; Theyel, 2000). However, responses of these questionnaires may be seriously biased, as respondents tend to present a socially desirable image of themselves or their companies (Golden, 1992). At the same time, research using environmental patents has been conducted at country or industry levels, ${ }^{1}$ but company level analyses are almost non-existent. Thus, we incorporate into previous environmental research this long-established measure of innovation.

\section{Theoretical Framework and Hypotheses}

Two different theoretical approaches have been commonly used in literature to offer insights regarding environmental issues: Institutional theory and the resource-based view of the company (RBV). While both theories make important explanatory contributions in their own right, they focus on different domains of organizational action. Institutional theory acknowledges the role of external forces in shaping organizational activities and emphasizes the importance of legitimacy. RBV, on the other hand, dictates that company's internal resources can be a source of competitive advantage in markets when the company's rivals cannot obtain like resources. In this paper, we argue that each of these approaches contains a kernel of truth that explains environmental innovation, but none provides by itself a full explanatory account of this phenomenon. We suggest that research on environmental innovation can be advanced by a conceptual merger of both frameworks. Indeed, recent studies from both strategic and environmental management (Bansal, 2005; Clemens and Douglas, 2006; Darnall, Henriques, and Sadorsky, in press; Oliver, 1997) have sought increasing explanatory power in the convergence of both perspectives.

\footnotetext{
${ }^{1}$ A summary of representative studies in the area is available from the authors upon request. 


\section{Institutional Theory and Environmental Issues}

Institutional theory (DiMaggio and Powell, 1983; Meyer and Rowan, 1977; Scott, 1995, 2005) focuses its attention on the role of social influence for social conformity in shaping organizations' actions. Because organizations are assumed to be approval-seeking, they are susceptible to social influence. One of the main theses of institutional theory is that organizations act to enhance or protect their legitimacy (Scott, 1995). By adopting strategies in adherence to institutional prescriptions, companies reflect an alignment of corporate and societal values (Meyer and Rowan, 1977). When companies conform to societal pressures, they gain a legitimacy that secures organizational success and survival (Aldrich and Fiol, 1994; DiMaggio and Powell, 1983; Oliver, 1991). Thus, concern over legitimacy influences companies by forcing them to adopt certain managerial practices that are expected to be socially valuable (Deephouse, 1999; Scott, 1995). Institutional theory does not directly address efficiency issues nor the impact of strategies on performance, since it explains the implementation of practices without obvious economic value. Yet it recognizes the value that these practices provide in terms of legitimacy and its importance for a company's endurance (Ashforth and Gibbs, 1990; Scott, 1995). A gain in legitimacy can benefit an organization since it aids in securing access to valuable resources, provides a license to operate and innovate, lowers risk, enhances reputation, and strengthens stakeholder relations (Deephouse, 1999; DiMaggio and Powell, 1983; Fombrun, 1996; Sherer and Lee, 2002; Staw and Epstein, 2000).

A conventional argument of institutional theory is that pressure for institutional conformity leads to a company's adoption of the same strategies and structures as those adopted by other actors within the organizational field. These "copycat" practices often lead organizations to resemble each other and beget the classical explanation of homogeneity across companies (i.e., isomorphism) (DiMaggio and Powell, 1983). Indeed, institutional theory has successfully explained how conforming to societal expectations increases legitimacy, reduces uncertainty, and increases standardization. However, institutional theory has been criticized (e.g., Kondra and Hinings, 1998; Powell, 1991) for ignoring organizational diversity and how organizations change since, under the institutional perspective, there are few incentives to innovate since adopting unique strategies can seriously hinder the company's legitimacy (Deephouse, 1996).

Institutional theory has been extensively used in environmental management (e.g., Bansal, 2005; Bansal and Clelland, 2004; Delmas, 2002; Hoffman, 1997, 1999, and 2000; Jennings and Zandbergen, 1995). For example, Hoffman (1997) studied the chemical and petroleum industries from 1960 to 1993, using institutional theory as the conceptual lens for understanding how these industries have changed due to increasing pressures for environmental management. From an institutional perspective, Bansal and Clelland (2004) showed that environmentallylegitimate companies incur less unsystematic stock market risk than illegitimate companies. Also applying institutional theory, Delmas (2002) explained the variation in the implementation of ISO 14001 across Europe and the United States. More recently, Bansal (2005) analyzed the influence of institutional factors on corporate sustainable development.

A key prediction of institutional theory applied to environmental issues refers to the gain in legitimacy. Because of their impact on the natural environment and society, companies tend to be scrutinized more intensely by different stakeholders like government, media, consumers, and activists. Given the increased social awareness of organizational wrongdoing and the explicit environmental demands, institutional theory predicts that companies can gain legitimacy by reducing their impact on the environment and exhibiting good environmental performance (Bansal, 2005; Bansal and Clelland, 2004). 


\section{Resourced-Based View of the Company and the Natural Environment}

The resource-based view of the company (RBV) (Barney, 1991; Wernerfelt, 1984) argues that value-creating strategies are those that create resources and capabilities with profit potential. Resources and capabilities include tangible inputs such as people, property, and capital, and intangible resources like skills and know-how (Barney, Wright, and Ketchen, 2001). The endurance of profit from these resources and capabilities are determined by their uniqueness, scarcity, value, inimitability, and non-substitutability (Barney, 1991; Barney, Wright, and Ketchen, 2001; Peteraf, 1993). These features enable a company to obtain above-normal rates of return since it is difficult for a company's rivals to obtain or duplicate these resources and capabilities in the market. Consequently, resources and capabilities ultimately define the company's competitive advantage. According to this perspective, the final goal of the company is to attain sustainable competitive advantage, and this occurs when the bundle of resources and capabilities provides above-average returns in the long-run (Porter, 2004). As a result, RBV assumes that resource choice, procurement, and creation are driven by economic and efficiency motives (Oliver, 1997).

In contrast to the institutional perspective, the RBV framework explains heterogeneity across companies, since factors that inhibit the imitations of resources increase variation in companies' strategies. The RBV approach suggests that, as resources become redundant, companies have to continually reinvent themselves through growth and investment, taking advantage of early adotoption, and tending to deploy resources sequentially as they develop (Eisenhardt and Martin, 2000; Peteraf, 1993; Wernerfelt, 1984). Thus, innovation is not only possible but probably essential for organizations to succeed. In other words, the capability to innovate has the potential to become a source of competitive advantage since innovations are knowledge-based, socially complex, and causally ambiguous, and thus more likely to be idiosyncratic to the company in which this capability resides (Barney, 1991; Barney, Wright, and Ketchen,, 2001; Grant, 1991; Peteraf, 1993). Indeed, it is a major challenge for technological innovators to obtain talented scientists and engineers and to develop successful innovation that can be taken to the market. Thus, innovations may be the path for organizations to become unique and sufficiently different to avoid competitors' imitation.

RBV is perhaps the most influential framework in environmental management, especially since the seminal work of Hart in 1995. He proposed the natural resource-based view of the company. In his article, Hart argued that good environmental behavior can be a source of competitive advantage. When companies effectively respond to environmental demands and challenges in innovative ways, they gain new resources and develop capabilities that can provide an edge over competitors. Environmental innovations can lead to more complex, environmentally benign products, processes and services. These in turn can lower overall company costs and legal liabilities (Christmann, 2000; Khanna and Damon, 1999; Sharma and Vredenburg, 1998), lead to price premiums (Shrivastava, 1995), enhance a company's reputation, and secure social legitimacy (Hart, 1995). Like other company-specific resources, these environmental capabilities that are difficult to create and imitate become embedded, valuable, and a source of long-term competitive advantage (Bansal, 2005; Hart, 1995; Russo and Fouts, 1997; Sharma and Vredenburg, 1998). Ultimately they also enhance the company's financial performance (Dowell, Hart, and Yeung, 2000; Hart and Ahuja, 1996; King and Lenox, 2002; Klassen and McLaughlin, 1996; Russo and Fouts, 1997). 


\section{Integrating Institutional Theory and Resource-Based View perspectives: An Environmental View}

The foregoing paragraphs summarize the key postulations from both conceptual perspectives. The hybrid framework we propose is motivated by the complementary nature of these two approaches and it is relevant since neither perspective in its own right has the capacity to provide a full explanation of organizational behaviors. For instance, institutional theory focuses on external forces and seeks to explain organization-context relations from an overarching social view, while RBV concentrates on the development of internal resources and capabilities. Thus, a combined framework allows us to examine the dynamics of the interface between institutional contexts and organizational level strategies (such environmental innovation) by highlighting their unique and complementary nature (Oliver, 1997).

Moreover, institutional theory puts emphasis on the legitimacy-seeking behaviors of companies. According to the institutional perspective, organizations conform to societal expectations in order to increase their legitimacy, resources, and survival capabilities, but reasons of efficiency are often ignored. Conversely, RBV can be criticized for excessive emphasis on resource markets and economically rational choices without taking into account the social context within which companies' choices are embedded and how this context might affect companies' sustainable competitive advantage development (Ginsberg, 1994; Oliver, 1997). However, other external circumstances beyond economic factors are also likely to affect the development of resources and competitive advantage (Barney, Wright, and Ketchen, 2001; Oliver, 1997). As stated by Oliver (1997), "resource selection and sustainable competitive advantage are profoundly influenced... by the institutional context" (Oliver, 1997, p. 698). Indeed, in real-life situations, a company is likely to contemplate both the relevance of proper responsiveness to institutional forces and the importance of creating valuable resources. Therefore, a combined approach can provide a clearer framework to explain decisions regarding competitive advantage creation.

Also, previous research has limited the influence of institutional pressures to the context of industries. Our combined framework helps to recognize that external pressures differ across organizations even when they operate in the same field, and this could have differential effects on companies (c.f., Hoffman, 2001; Milstein, Hart, and York, 2002). Finally, little attempt has been made to explore how institutional pressures may affect the company's ability to innovate. The combination of institutional theory and RBV provides a convenient framework to test the extent to which institutional pressures are in fact constructive in enhancing the company's outcomes.

Different implications can be derived from the combination of these two diverse but complementary theoretical perspectives: (1) Institutional pressures indicate the way the company is expected to behave (DiMaggio and Powell, 1983; Meyer and Rowan, 1977; Scott, 1995). They define a company's socially acceptable conduct and shape decisions regarding organizational efforts and resource allocations (Oliver, 1997); (2) Institutional pressures create opportunities and companies can seize them by responding strategically. That is, companies do not remain impassive to external influence and they can respond strategically to institutional pressures (Hoffman and Ventresca, 2002; Lawrence, 1999; Oliver, 1991, 1997). Innovating within the limits established by institutional contexts allows companies to conform to social demands while searching for competitive advantage; (3) Higher degrees of institutional pressures require more unequivocal and definitive responses from the company in order to avoid losses from the misfit between organizational actions and societal expectations. That is, 
the more the company fails to achieve institutional demands, the greater the subsequent effort it has to devote to reduce dissonance between organizational actions and societal requirements (Milstein, Hart, and York, 2002); (4) A company's decisions regarding social demands are also marked by economic components that make them more akin to market demands. In tandem, economic choices and resource selection are influenced by societal imperatives (Oliver, 1997). Thus, a company needs to accomplish an appropriate combination of institutional and efficiency responsiveness (Martinez and Dacin, 1999); (5) The development of key resources and capabilities together with the achievement of legitimacy gained through social compliance are vital for organizational success and survival (Barney, 1991; DiMaggio and Powell, 1983; Meyer and Rowan, 1977; Porter, 2004; Scott, 1995; Wernerfelt, 1984).

The application of these premises to the natural environment suggests that institutional forces will pressure companies to behave according to their environmental concerns. Institutional pressures constrain organizations' actions but at the same time create business opportunities. In order to seize these opportunities, companies need to develop increasingly novel and complex technologies that reduce or eliminate toxic waste so that they are not mimicked by rivals. In this context, innovation in environmental-related issues is essential to create capabilities that enable the company to seize market opportunities for sustainable development (Bansal, 2005; Hart, 1995).

Furthermore, institutional pressures do not come in isolation. Actors within an institutional field do not only exert pressure, but often provide guiding principles, technical assistance, and specialized information that define actions deemed legitimate. For instance, the Environmental Protection Agency (EPA) enforces environmental regulations and persecutes violators but it also launches initiatives like the EPA 33/50 program, which provided companies with professional information to reduce discharges of industrial toxic pollutants (Arora and Cason, 1996). Similarly, the Chemical Manufacturers' Association (a trade association of the U.S. chemical sector) created the Responsible Care Program to help its members reduce toxic emissions by providing a series of principles and managerial practices (King and Lenox, 2000). These external support and assistance may be additional incentives for companies to embark on environmental innovations.

Environmental innovations appear as an advantageous strategic direction because, on the one hand, they offer an effective response to the environmental demands of stakeholders of the company since these innovations are intended to reduce or eliminate the toxic burden of production processes to the natural environment. On the other hand, environmental innovations are, by definition, company-specific and hard to copy (Markman, Espina, and Phan, 2004). Moreover, the value of environmental innovation derives not only from the potential economic gains of the innovation but also from the legitimacy obtained by conforming to societal expectations. By innovating in environmental-related issues, companies that respond to the external demands also obtain legitimacy and secure their survival and, at the same time, they create resources and capabilities that are unique, difficult to imitate, and of recognized value in obtaining abnormal returns. And, even when R\&D activities are inherently risky because they provide greater variability of outcomes, require long-term investments and entail greater probability of disruption, environmental innovation could be a less costly choice than the risk of being stigmatized as irresponsible corporate citizens. A misfit between stakeholders' expectations and a company's actions can be deadly for the company since it can result in loss of legitimacy, deterioration of reputation, unfair contracts, and a consequently higher likelihood of failure (Deephouse, 1999; Dowling and Pfeffer, 1975). Based on these arguments, we contend that institutional forces have a positive impact on environmental innovation. 


\section{Regulatory Forces and Environmental Innovation}

Scott (1995) identified three basic "pillars" of institutions - regulative, normative, and cognitive that provide structure and meaning to organizational behavior. The regulatory element provides explicit guidance to organization through rules, controls, rewards, and sanctions. The normative element guides behavior through a less explicit system of norms and values. The cognitive pillar refers to cultural elements that govern choice, often without receiving conscious thought. Although Scott recognized that all institutions combine the three elements, he suggested in a recent review of institutional theory that regulatory and normative forces are of special interest when analyzing institutional pressures (Scott, 2005).

Regulatory forces can adopt different forms like persuasion, collusion, or coercion. Typically, regulatory forces are conceived by governments. One positive outcome of the organization being subject to regulatory forces is the legitimacy derived from the recognition of the organization's existence by the regulatory jurisdiction, allowing it to function and operate (Deephouse, 1996).

Oliver (1991) suggested that when the degree of legitimacy and economic gains attainable from conformity to institutional pressures combine with a high level of legal coercion, the more likely it is that the company conducts activities in line with such pressures. Consequently, to the extent that environmental strategies are a source of legitimacy and provide an economic edge, greater degrees of regulatory forces should be reflected in more environmental initiatives. This prediction is also consistent with RBV arguments used in environmental management literature. According to this view, pollution is seen as inefficiencies in the use of inputs, and flaws in product design and production (Hart, 1995; Porter and van der Linde, 1995a, and 1995b; Shrivastava, 1995). Environmental regulations may induce companies to use alternative processes and root out these inefficiencies, enhancing profitability. As a result, companies that face stronger environmental regulation are more likely to innovate, and innovate more, than companies with weaker regulatory forces (Porter and van der Linde, 1995b). Empirical evidence at country and industry levels supports this prediction (Brunnermeier and Cohen, 2003; Jaffe and Palmer, 1997; Lanjouw and Mody, 1996).

Hypothesis 1a (H1a): Regulatory forces will have a positive impact on environmental innovation.

\section{Normative Forces and Environmental Innovation}

Normative influences arise from values and norms (Scott, 1995). These norms and values are defined by a social interaction context that identifies appropriate behavior for group members (Meyer and Rowan, 1977). As a result, normative influences typically come from the industry and professional organizations that establish standards for operations (Scott, 1995, 2005).

Normative influences, often implicit, are related to the issue of legitimacy. In their quest for legitimacy, organizations compare themselves to their peers and try to behave in accordance to standards established by the industry and other members of the organizational field (DiMaggio and Powell, 1983; Scott, 1995). Consequently, those companies positioned away from those standards face greater normative pressures than those that meet or surpass such standards. As a result, companies that perform below the 'environmental' level assumed to be acceptable by the industry are expected to have a greater incentive to innovate. Innovation in environmental- 
related issues can help the company to reduce distances with respect to other members of the industry, and consequently enhance legitimacy.

Previous works in strategic environmental management (King and Lenox, 2000; Klassen and Whybark, 1999) claimed that poorly performing companies are likely to adopt strategically green initiatives established by the industry to which they belong. King and Lenox (2000) argued that this is so because, on the one hand, these are the companies that can benefit most from these initiatives and, on the other hand, they can obtain an insurance against risks like claims for negligence and costly regulatory sanctions. Thus, we expect a positive link between normative forces and voluntary initiatives like environmental innovation.

Hypothesis 1b (H1b): Normative forces will have a positive impact on environmental innovation.

\section{The Moderating Role of Companies' Resources}

Strategy is constrained by, and dependent on, the company's resources profile (Bourgeois, 1981; Cyert and March, 1963; Pfeffer and Salancik, 1978). Resources give the company leeway in choosing the best strategy in response to the external requirements (Bourgeois, 1981; Sharfman, Wolf, Chase, and Tansik, 1988) and, at the same time, are critical determinants of knowledge creation and organizational capabilities (Lieberman and Montgomery, 1998; Makadok and Barney, 2001). Moreover, resources have a drastic influence on the company's environmental performance (Kassinis and Vafeas, 2006). Therefore, resources are likely to play a main role in the relationship between external influences and environmental innovation. Specifically, we propose that the effect of institutional pressures on a company's environmental innovation is contingent on two characteristics of resources, namely availability and specificity.

Availability of resources, often called organizational slack, refers to "that cushion of actual or potential resources which allows an organization to adapt successfully to internal pressures for adjustment or to external pressures for change in policy as well to initiate changes in strategy with respect to the external environment" (Bourgeois, 1981). Higher levels of resources provide the company with greater flexibility towards, and better understanding of, external influences (Cyert and March, 1963; Meyer, 1982). Resources enhance an organization's adaptability because strategic choices are more abundant, and it can respond faster and more effectively than companies with limited resources. For instance, Smith and colleagues (1991) contended that companies with more ample resources can invest in sophisticated information systems that enhance the understanding of external influences and, because of those resources, companies can respond in unique and competitive manners. Applying this logic to our setting, it indicates that companies with more resources are able to be more sensitive to the environmental demands that emanate from external factors and can afford entirely new actions, like the development of environmental-friendly products or processes. In contrast, strategic choices are constrained for companies with low resources as they have limited options, reduced capability of change, and can be forced to either ignore environmental demands or respond to them in a more cosmetic way.

Additionally, resources buffer companies from uncertainty and enable them to take risky initiatives in response to external pressures (Chattopadhyay, Glick, and Huber, 2001; Nohria and Gulati, 1996). R\&D projects are inherently risky given that innovation efforts might fail despite the best intentions of managers. Resources allow companies to generously experiment with novel ideas and introduce new products in the market without the restraints faced by low- 
resource companies (Moses, 1992). Therefore, organizations with higher levels of resources are more likely to engage in more innovative projects that might not be approved in more resource-constrained companies (Cyert and March, 1963). This logic indicates that, given that institutional pressures for environmentally good behaviors can spawn business opportunities (Darnall, Henriques, and Sadorsky, 2005; Hoffman and Ventresca, 2002; Sharma, 2000), those companies with more resources would innovate more in environmental-related projects, while companies lacking resource would see these initiatives as very risky courses of action and, thus, avoid them.

Aforementioned arguments not only apply to tangible resources like financial slack, but also are applicable to intangible resources such as the stock of technological knowledge. Makadok and Barney (2001, p. 1624) argued that "the potential value of a new resource depends on the pre-existing stock of resources that are already controlled by that firm". This is particularly true for innovation activities since the company's ability to innovate increases its absorptive capacity to learn and take advantage of existing and new technological knowledge (Cohen and Levinthal, 1990). Therefore, companies with a large stock of intangible resources such as preexisting technological knowledge would be more able to conduct R\&D activities directed to develop environmental innovations as a response to institutional pressures, than those companies with less innovation resources. In addition, companies respond with environmental innovation that complements the development of company-specific resources (e.g. Russo and Fouts, 1997; Christmann, 2000; Klassen and Whybark, 1999; Aragón-Correa et al, 2004; Shrivastava, 1995).

Moreover, companies with more resources have more capital at risk than companies lacking those resources and, therefore, would be more willing to protect their interests by expanding their portfolio of patents. This is particularly true when the company's resources are very specific. A well established argument from transaction cost economics is that contracts are less effective against expropriation the higher the specificity of assets involved, that is the higher the cost of redeploying company resources (Klein, Crawford, and Alchian, 1978; Williamson, 1985). For instance, Hall and Ziedonis (2001) and Ziedonis (2004) applied this argument to explain the strong rise of the propensity to patent in the semiconductors sector after the 1980s' strengthening of U.S. patents rights. Authors found that companies with high capital intensity (a proxy for the level of asset specificity) participate in "patent portfolio races" to respond strategically to hold-up problems. Because heavy polluters are subject to more stringent external pressures, which in turn increase their chances of bankruptcy (Cohen, 1987), those companies with larger sunk costs in specific assets have more to lose and, consequently, will see more value in securing environmental ideas by patenting environmental-related projects more heavily. Moreover, the greater potential losses in the case of bankruptcy for these companies put them in a weak bargaining position in case they need to rely on external providers of green technologies. This last argument further increases the incentives of capitalintensive companies towards environmental patenting when they face strong institutional pressures.

Hypothesis 2 (H2a): Availability of resources moderates the relationship between institutional forces and environmental innovation.

Hypothesis 2 (H2b): Specificity of resources moderates the relationship between institutional forces and environmental innovation. 


\section{Methods}

\section{Sample and Data Collection}

We test our hypotheses with a sample of highly innovative companies belonging to the 20 most polluting sectors according to the EPA's TRI (Toxic Release Inventory) program. After compiling all the necessary information from three different databases, we end up with an unbalanced panel of 340 U.S. publicly traded companies for the period 1997-2001. The final list of companies was constructed as follows: First, we identified the 20 most polluting sectors by ranking industry sectors at the 2-digit SIC codes based on the total amount of toxic emissions for the period under analysis using the TRI database. ${ }^{2}$ Then we obtained the list of U.S. companies belonging to these top polluting sectors from COMPUSTAT database. Finally, we checked at the U.S. Patents and Trademarks Office which of these companies had more than 40 patents in the analyzed period and obtained the final sample of highly innovative and polluting companies. We focus on these companies since they are expected to have both the motivation and the capability to successfully undertake environmental R\&D activities. However, an interesting observation from our sample is that only around 15\% of these companies have at least one environmental patent in the analyzed period.

Once the list of companies had been identified, the data about environmental innovations were obtained from Nameroff et al. (2004) who used information from the CHI's Patent Citation Indicators database. This database tracks information about environmental patents of companies with more than 40 patents in the last 5 years. This database represents more than 60\% of all U.S. patents granted since 1992 and more than 70\% of those patents that are not held by private individuals. ${ }^{3}$ In their study, the authors provided company-assignees of over 3,200 environmental-related patents during 1983-2001 and the number of forward citations for each of the patents. We aggregated data by parent companies of these companies using multiple sources, including Mergent Manuals, which compile data regarding subsidiaries, COMPUSTAT database, and companies' websites.

Information regarding institutional forces was gathered from the U.S. Environmental Protection Agency (EPA). Finally, the remaining variables for our study were compiled from the COMPUSTAT database.

\section{Variable Definitions}

\section{Dependent Variable}

We use patent data to measure a company's ENVIRONMENTAL INNOVATION. Patent counts have basically two limitations as measures of innovation output. First, not all innovations are expected to be patented. Previous evidence from survey data (Levin et al. 1987; Cohen et al., 2000) has reported that the effectiveness of patents as protection mechanisms varies strongly across sectors. By including sector-fixed effects in the estimation, we take into account, at least partially, this

\footnotetext{
2 The 20 most polluting sectors for the analyzed period, using the 2-digit SIC code, are: 10, 50, 33, 49, 28, 36, 12, 13, 20, 32, 30, 51, 26, 34, 29, 31, 35, 37, 24, 27.

3 See Nameroff et al. (2004) for a more comprehensive description of the CHI Research Inc database. A full description of the patent search filter used to identify environmental patents is available at http://www.chemistry.org/greenchemistryinstitute
} 
issue as we allow for the time-invariant differences in the likelihood of patenting a given environmental innovation by sector. A second problem of using patents as an indicator of the amount of environmental innovation is that patent counts do not distinguish among different qualities of innovative outputs. That is, some patents are very valuable while some are worth almost nothing. Recognizing this problem, Lanjouw and Schankerman (1999) and Hall, Jaffe and Trajtenberg (2000) among others, have found more creative ways to measure the value of patents. For instance, using the number of citations received by a patent instead of using patent counts, or computing an index where patents are weighted by their corresponding citations. Along this line, we use the total number of citations received by the patents granted each year as the dependent variable and show that the reported results are robust to other value-adjusted measures of innovation output.

\section{Independent Variables and Controls}

In order to compute a measure of the strength of REGULATORY FORCES faced by the company we use information from the "Enforcement and Compliance Assurance Accomplishment Report", which is issued annually by the Office of Enforcement and Compliance Assurance of the U.S. Environmental Protection Agency (EPA). These reports detail "significant criminal, civil, and administrative enforcement actions and the results achieved on behalf of the American public and the environment" (U.S. EPA, 1996:1-1). We reviewed these enforcement actions to identify those cases where the companies of our sample were defendants in environmental lawsuits, and used the number of cases per year as a measure of the strength of regulatory forces faced by the company in that year. Similar measures have been validated in previous environmental studies (e.g. Kassinis and Vafeas, 2002). We measure NORMATIVE FORCES using information from EPA's TRI program. Use of TRI data is well established in management research on environmental impact of corporations (e.g. Anton et al., 2004; e.g. King and Lenox, 2002; Klassen and Whybark, 1999; Russo and Harrison, 2005). Under the EPA's Emergency-Right-to-Know Provision, industrial facilities with 10 or more full-time employees that release any listed toxic substance in excess of minimum reporting threshold to four different media (namely air, water, land, and underground injection) are required to report the type and amount of emissions to the EPA (EPA, 2002). Early studies simply used the sum of annual emissions of all TRI substances released in a given year as a proxy for the company's potential harm to human health or the environment (Dooley and Fryxell, 1999; Khanna and Damon, 1999). However, TRI data reflect releases of noxious emissions but not the level of exposure the public or the ecosystem sustains (EPA, 2002). While recent studies (e.g. King and Lenox, 2002; Russo and Harrison, 2005) tried to mitigate this shortcoming by weighting emissions by the toxicity level of chemical agents, these weighting system are not without limitations (see Toffel and Marshall, 2004, for a full discussion on the issue). The main problem is that these systems do not account for the medium in which the chemical agent is released (e.g. air, water, land) and it is hard to determine the bases on which the toxicity level for a particular chemical was established (Toffel and Marshall, 2004). To address these drawbacks, we weigh chemicals using the Human Toxicity Potential factor (HTP) developed by Hertwich et al. (2001). These authors used the CalTOX model, which is a sophisticated and comprehensive multimedia fate and transport model. The result is an index that reflects the potential harm to human health of a unit of chemical released into the environment in terms of benzene equivalence (carcinogens). A key feature of this toxicity weighing method is that it provides each chemical with individual HTP values for different release media. This allows a more precise assessment of the harm that chemical releases have on human health (Hertwich, 
Mateles, Pease, and McKone, 2001). We weight each chemical release by its corresponding HTP value in a given year considering the medium into which it was released. We then aggregate the results, first across chemicals at facility level, and then finally by parent company. This measure was recently validated by Berrone and Gómez-Mejía (2006).

We assume that the level of emissions is strongly correlated with the strength of normative pressures received by the company and thus use them as a proxy taking logarithms to approach normality. From our theoretical framework, institutional forces are expected to increase the incentives to develop environmental innovations. Yet, these pressures are unlikely to have an immediate effect at generating an environmental innovation and thus it is reasonable to account for certain lag. Thus, we incorporate both measures of institutional forces with a twoyear lag.

As a central innovation input we use the variable R\&D INTENSITY which is measured during the year in which the patents are granted. Previous empirical papers (for instance Hall Griliches and Hausman, 1986) focused on estimating the lag structure of the patent production function from past R\&D expenditures and concluded that the lag structure is very poorly identified given the high within-company correlation of R\&D spending over time. When lags are included in the regression, the sum of the estimated coefficient on the R\&D variables is close to the coefficient of the contemporaneous level of R\&D expenditures when no lag is included. For this reason, we use the contemporaneous level of $R \& D$ as a measure of innovation input in the patent production equation. We normalize the level of $R \& D$ expenditures by the number of employees to avoid confounding its effect with a size effect, and finally take the logarithm. R\&D effort measures the company's R\&D intensiveness and is expected to have a positive sign in the patent production function. Additionally, as explained in the previous section, we expect companies that are more specialized in R\&D activities to be more likely to undertake environmental R\&D if subject to institutional pressures.

The variable CAPITAL INTENSITY is measured by logarithm of the ratio of the book value of the company's plant and equipment and the number of employees. We incorporate this variable in the baseline regression as a way to allow for the potential strategic motivation to ask for patents in general to avoid hold-up (Hall and Ziedonis, 2001). Following the rationale that was developed in the previous section, capital-intensive companies are expected to be more likely to develop environmental innovations once subject to institutional pressures.

We use two different measures of organizational slack based on previous literature (Bromiley, 1991; Fleming and Bromiley, 2003). ORGANIZATIONAL SLACK1 is the ratio of working capital to sales and ORGANIZATIONAL SLACK2 is the ratio of the net income and revenues (profit margin). We expect the interaction between organizational slack and institutional pressures to have a positive effect on the level of environmental innovations.

We allow for potential economies of scale in patenting including the variable SIZE which is measured as the logarithm of employment. All the estimated models include sector, ${ }^{4}$ location $^{5}$ and year fixed effects to allow for unobserved heterogeneity between sectors and locations, and for annual trends that could affect the level of patenting.

\footnotetext{
${ }^{4}$ Sectors are identified at the 2-digit level SIC codes.

${ }^{5}$ Location of the parent company (state dummy if it is a US company or country dummy if it is foreign company). 
Finally, for some few companies R\&D expenditure is missing or not reported. We imputed a value of zero R\&D expenditures to those companies and included an indicator variable NO R\&D to control for potential bias in the estimation of the coefficient of R\&D effort.

\section{Empirical Model and Estimation Method}

Given the count nature of the dependent variable, we need to use non-linear estimators as Poisson and Negative Binomial regression models. The use of these models is common in empirical studies on patenting activity. Poisson models assume that the mean and the variance of the dependent variable are equal. Preliminary exploratory analysis of the data using the Lagrange Multiplier (LM) test rejected the pure Poisson model in favor of a model where the variance is proportional to the mean. Thus, for the purpose of this paper we only present results of the negative binomial estimations. The baseline specification for the level of environmental innovation is the following:

ENVIRONMENTAL INNOVATION $_{i t}=$

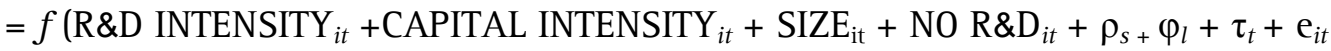

where $i$ denotes companies, $t$ years, $\rho_{s}$ sector dummies, $\varphi_{l}$ location dummies, $\tau_{t}$ year dummies, and $\mathrm{e}_{i t}$ is the error term. The baseline specification includes R\&D INTENSITY.

To test hypotheses $1 \mathrm{a}$ and $1 \mathrm{~b}$, we incorporate our two lagged measures of institutional forces (REGULATORY FORCES and NORMATIVE FORCES) in the baseline equation. To test the moderator role of the availability of resources (hypothesis 2a), we incorporate ORGANIZATIONAL SLACK1 and 2 each at a time and their interactions with both types of institutional pressures. Finally to test the moderator role of the specificity of resources (hypothesis 2 b), we interact both measures of institutional pressures with R\&D INTENSITY and CAPITAL INTENSITY respectively which indicate to what extent the company is specialized in R\&D activities and the importance of fixed investments respectively.

\section{Results}

Descriptive statistics are reported in Table 1. On average there is one environmental patent for every four companies in the sample, and those companies with environmental patents receive on average 1.74 citations. Concerning institutional pressures, although all companies belong to top polluting sectors, we have companies that do not generate toxic emissions in the sample. With regard to regulatory pressures, on average only $4 \%$ of the companies report litigations around environmental issues. Average number of employees and R\&D expenditures denote that we are working with a sample of big companies with experience in R\&D activities.

Results of the estimated patent production functions are presented in Tables 2 and 3. The estimations of the basic specification are shown in Model 1. As expected, bigger companies, companies with higher intensity of R\&D investments and companies with higher levels of capital intensity generate more environmental innovations.

We first examine the impact of institutional forces on environmental innovation (Hypotheses 1a and 1b) by including our two year lagged measures of institutional forces in Model 2. The inclusion of these two variables increases the explanatory power of the model. Both 
REGULATORY FORCES and NORMATIVE FORCES have a positive and highly significant effect on the level of environmental innovations generated by the company, providing support for both hypotheses. Although both types of institutional forces have a positive effect on the level of environmental innovations, the coefficient of REGULATORY FORCES is significantly higher than that of NORMATIVE FORCES meaning that the former have a much larger effect on environmental innovations than the latter.

In Models 3 and 4 we explore the moderating effect of the availability of resources on the generation of environmental innovations (Hypothesis 2a). Both measures ORGANIZATIONAL SLACK1 and ORGANIZATIONAL SLACK2 are lagged two periods as our measures of institutional pressures. Against our expectations, both measures provide similar results; the higher the level of organizational slack the less reactive the company will be to institutional forces. Again the effect is weaker or not significant when we consider normative pressures.

Finally, in Table 3 we explore the extent to which resource specificity has a moderating effect on the level of environmental innovations. In Model 5 we include the interaction between both types of institutional pressures and R\&D INTENSITY and find a positive and significant coefficient for regulatory forces while the coefficient is not significant for normative forces. Regulatory forces are associated with more environmental innovations in companies that are more R\&D intensive. In Model 6 we introduce the interaction between both institutional pressures and CAPITAL INTENSITY and find again that regulatory forces induce more environmental innovations in companies with higher level of capital intensity, while the interaction with normative forces is not significant.

In summary, the empirical analysis developed here suggests that institutional pressures have an effect on the level of environmental innovations generated by the company. This effect is moderated by the quantity and type of resources owned by the company and thus one should not expect different companies to react to the same extent to institutional pressures. We find that a company will be more sensitive to institutional pressures the lower its level of organizational slack, the higher its level of R\&D intensity and capital intensity. We also find that regulatory forces are more effective than normative forces in stimulating the company to undertake environmental R\&D.

Having established our basic finding, that the availability and type of resources moderate the effect of institutional pressures on environmental innovations, we implemented the following robustness checks. First, we checked that the obtained results do not depend on the selected measure of environmental innovation by exploring with other value-weighted measures previously used in empirical literature on patents. Results are qualitatively unchanged when we weight each patent by the proportion of the citations received by the company with respect to the number of citations received by companies from the same sector. Results also hold if we use the sum of citations plus patents as an alternative environmental innovation measure. This measure allows us to distinguish between companies with no patents and companies with patents but no citations, while the traditional value-weighted measures do not. Finally, results also hold when we include company fixed effects in the model; however, we lose several observations due to the number of companies with zero patents during the period and to companies that only have data for a single year. For this reason we do not report these results as the central specification of the paper, and focus on the pooled cross section model. In any case, we interpret the results of the model with company fixed effects as an indication that it is not likely that the reported significant effects are due to unobserved company level heterogeneity. 


\section{Discussion and Conclusion}

In this study, we proposed that regulatory and normative forces in favor of environmental issues spawn innovative responses in companies. Such innovations are expected to satisfy the demands of stakeholders, which in turn, will grant legitimacy expected to be beneficial to the organization. We tested our theory using a sample of 340 publicly-traded companies from U.S. polluting industries and found support for our main hypotheses. Regulatory and normative forces have their predicted positive association with environmental innovation. The interaction between institutional pressures and the type of resources (capital and R\&D intensity) are positively associated with environmental technology productivity when regulatory forces are present. Interestingly, however, the interaction of institutional forces and organizational slack is negatively related to environmental innovation. Taken together, these results provide substantial support for our contention that external forces spawn environmental-related technologies according to the resources profile of the company, suggesting that our combined approach that considers institutional and RBV predictions is meaningful. The results of this study are important for both researchers and managers, as conclusions derived are not only theoretically significant but they have a practical content.

\section{Contributions and Implications for Research}

Our work has theoretical, empirical, and methodological contributions and implications to different management streams of research. Theoretically, we contribute to institutional theory and the resource-based view of the company. The predominant view of institutional theory is that external pressure leads to corporate isomorphism (Deephouse, 1996; DiMaggio and Powell, 1983). On the other hand, the RBV approach suggests that heterogeneity among companies is a consequence of the quest for unique resources. In this study, we have argued that both theoretical approaches can be integrated to offer a more holistic picture of the corporate phenomena, enhancing our understanding of how companies build competitive advantage. This combined framework could affect the way researchers examine competitive advantage creation as it suggests that institutional pressures may come into play when resources and capabilities are developed. That is, institutional pressures can be a source of competitive advantage as they establish the boundaries within which organizations can be creative and innovative.

Empirically, we showed that both regulative and normative forces spawn environmental innovation. The fact that the coefficient of regulatory forces is higher than that of normative forces could suggest that the potential legitimacy and economic costs of not reacting to institutional pressures are higher for regulatory forces than for normative forces. An alternative explanation could be that companies subject to normative forces rely more on other mechanisms to gain legitimacy rather than on investing in environmental innovations to comply with normative pressures.

We also found that the impact of institutional pressure on innovation is contingent on resources. We found that companies with larger sunk investments in production facilities are more likely to respond to institutional pressures in novel and matchless manners by undertaking environmental R\&D. For these companies, the potential losses in case of being forced to shut down a given production plant as a result of a preliminary injunction may be extremely high given the specificity of the assets involved. Thus, because these companies have more at risk than other companies with lower levels of fixed investments, they may use environmental patenting as a strategic shield to safeguard their assets from potential losses. 
Additionally, we found that the level of R\&D intensity of the company also moderates the relationship between institutional forces and innovation. Companies more specialized in R\&D activities are more likely to comply with institutional pressures by undertaking environmental $R \& D$ since they have more expertise and are therefore in a better position to obtain returns from R\&D expenditures in environmental issues. R\&D skills are difficult to acquire, and thus, companies without R\&D experience may find it more attractive to rely on external providers of environmental technologies or/and implement other kind of actions to conform to institutional pressures.

Contrary to our expectation, however, we found that institutional forces have lower impact on innovation in those companies with more organizational slack. These results are interesting, but challenging to interpret. One possible explanation is that companies may use slack as a buffer between themselves and institutional demands and thus sense little pressure to respond to such demands. It could be the case that companies with available resources may prefer to pay legal, economic, and social sanctions instead of changing products or processes by engaging in risky environmental projects. In any case, our finding suggests both the type and the amount of resources play a key role in converting external pressures into innovative outcomes.

This article also fuels the ongoing debate regarding the effectiveness of government in promoting environmentally-desirable outcomes. Our findings suggest evidence that the efforts of U.S. governmental agencies has a positive influence on environmental innovation. Further analysis of environmental regulations and their enforcement mechanisms could shed some light on the characteristics that other regulatory bodies could benchmark in order to work efficiently. However, our results should be viewed with caution as our measure of regulatory forces does not distinguish the type or duration of these enforcement actions. Future research should attempt to track these issues.

Methodologically, we contribute to the environmental research by using patent data at the company level to assess environmental innovation. Very little research approached environmental innovation as indicated by patent activity and the few exceptions were conducted at country or industry levels. Additionally, and in line with previous studies on patents, we find that it is important to use value-adjusted patent measures to identify the main effects.

\section{Implications for Managers}

External pressures towards more corporate responsibility require environmental strategies to conform to institutional demands, ensure societal legitimacy, and secure organizational success. Given that a company's competitive advantage depends on its ability to innovate in ways that allow it to change to new scenarios that its rivals cannot easily imitate, environmental innovation appears to be a valuable policy for managers to follow.

Our work suggests that paying attention to external influences may be a source of inspiration for managers to develop unique resources. However, this does not imply that managers need to wait for unavoidable pressures before developing environmental innovation. Decision makers can be proactive by scanning the environment and take the lead on this type of activity since it is expected to have a salutary effect on company performance.

An important issue is that the presence of resources does not guarantee that institutional pressure will be transformed into productive innovation. On the contrary, our results suggest that managers with slack may adopt a risk-averse strategy by avoiding environmental

16 - IESE Business School-University of Navarra 
initiatives. This posture could have deleterious effects on company performance and thus should be taken into account by monitoring agents such as the board of directors.

Finally, managers should be aware of the differences that exist between companies that are specialized in R\&D activities and companies without such experience. Our findings suggest that the former can more easily respond to institutional pressures by developing environmental innovations than the latter. Thus, managers should turn their attention to the efficient use of their resources.

\section{Caveats and Future Research}

Our study is not without limitations. At least three caveats deserve to be mentioned, which could be rectified in future research. First, we concentrated our analysis on publicly-traded companies in the U.S. context. Thus, our findings may not be open to generalization about privately-held companies, which may consider different factors in strategic choices and in strategies themselves (Trostel and Nichols, 1982), nor to other geographical regions. Future research can extend the analysis to organizational structures like privately-owned companies or family companies. Also, our work could be extended by studying environmental innovation in non-U.S. contexts to account for differences in regional environments.

A second caveat refers to the boundaries of our analysis. Even though we have limited ourselves to regulatory and normative forces, clearly, other factors are also involved in facilitating environmental innovation. Particularly interesting is the study of the "cognitive pillar", which we have omitted in our work. Cultural elements such as individual values are likely to govern environmental choices and strategic decisions (Bansal and Roth, 2000). This issue presents both opportunities and challenges to future research given that assessment of these data is often difficult and severely limited.

Another caution worth noting is that in this paper we do not analyze the impact of environmental innovation on either financial or environmental performance. It would be very interesting to explore whether those companies that develop environmental innovations reduce their levels of emissions and/or obtain a financial benefit with respect to companies that do not.

Finally, another exiting avenue for future research is the extent to which companies develop environmental innovation to later commercialize them in the market (through licensing, for instance) instead of internal use. The decision to whether "make or buy" may play a key role in environmental issues and research could be enhanced by developing this line of inquiry.

\section{Final Comment}

Increased social awareness of organizational wrongdoing and stakeholder pressures have placed environment concerns as an important part of the strategic choices of companies. Therefore, understanding the determinants of environmental innovation and its relationship with company performance is of critical importance to the effective management of corporations. We hope our work contributes to this goal. However, it is important to remember that environmental innovation is not only relevant in economic terms, but also from a social point of view as it is intended to alleviate a noxious burden shouldered by society as a whole. 


\section{References}

Aldrich, H. E. and C. M. Fiol (1994), "Fools rush in? The institutional context of industry creation," Academy of Management Review, 19, pp. 645-670.

Anton, W. R. Q., G. Deltas, and M. Khanna (2004), "Incentives for environmental self-regulation and implications for environmental performance," Journal of Environmental Economics and Management, 48 (1), pp. 632-654.

Arora, S. and T. N. Cason (1996), "Why do companies volunteer to exceed environmental regulations? Understanding participation in EPA's 33/50 program," Land Economics, 72 (4), pp. 413-432.

Ashforth, B. E. and B. W. Gibbs (1990). "The double-edge of organizational legitimation" Organization Science, 1 (2), pp. 177-194.

Balkin, D. B., G. D. Markman, and L. R.Gómez-Mejía (2000), "Is CE0 pay in high-technology companies related to innovation?," Academy of Management Journal, 43 (6), pp. 1118-1129.

Bansal, P. and K. Roth (2000), "Why companies go green: A model of ecological responsiveness," Academy of Management Journal, 43 (4), pp. 717-736.

Bansal, P. and I. Clelland (2004), "Talking trash: Legitimacy, impression management, and unsystematic risk in the context of the natural environment," Academy of Management Journal, 47 (1), pp. 93-103.

Bansal, P. (2005), "Evolving sustainably: A longitudinal study of corporate sustainable development," Strategic Management Journal, 26 (3), pp. 197-218.

Barney, J. (1991), "Company resources and sustained competitive advantage," Journal of Management, 17 (1), pp. 99-120.

Barney, J., M. Wright, and D. Ketchen (2001), "The resource-based view of the firm: Ten years after 1991," Journal of Management, 27, pp. 625-641.

Berrone, P. and L. R. Gómez-Mejía (2006), "Do companies compensate their CEOs for good environmental performance?," paper presented at the Academy of Management, Atlanta.

Bourgeois, J. (1981), "On the measurement of organizational slack," Academy of Management Review, 6 (1), pp. 29-39.

Brunnermeier, S. B. and M. A. Cohen (2003), "Determinants of environmental innovation in US manufacturing industries," Journal of Environmental Economics and Management, 45, pp. 278293.

Clemens, B. and T. J. Douglas (2006), "Does coercion drive companies to adopt 'voluntary' green initiatives? Relationships among coercion, superior company resources, and voluntary green initiatives," Journal of Business Research, 59 (4), pp. 483-491.

Cohen, M. A. (1987), "Optimal enforcement strategy to prevent oil spills: An application of a principal-agent model with "Moral Hazard", Journal of Law and Economics, 30 (1), pp. 23-51.

Cohen, W. and D. A. Levinthal (1990), "Absorptive capacity: A new perspective on learning and innovation," Administrative Science Quarterly, 35 (1), pp. 128-152. 
Cyert, R. and J. March (1963) "A behavioral theory of the company," Prentice-Hall, Englewood Cliffs, NJ.

Chattopadhyay, P., W. H. Glick, and G. P. Huber (2001), "Organizational actions in response to threats and opportunities," Academy of Management Journal, 44 (5), pp. 937-955.

Christmann, P. (2000), "Effects of 'best practices' of environmental management on cost advantage: The role of complementary assets," Academy of Management Journal, 43 (4), pp. 663-680.

Darnall, N., Henriques, I., and Sadorsky, P. (2005), An international comparison of the factors affecting environmental strategy and performance. Paper presented at the Academy of Management Best Conference Paper, Hawaii.

Darnall, N., I. Henriques, and P. Sadorsky, "Do environmental management systems improve business performance in the international setting?," Journal of International Management. (in press).

Deephouse, D. L. (1996), "Does isomorphism legitimate?," Academy of Management Journal, 39 (4), pp. 1024-1039.

Deephouse, D. L. (1999), "To be different, or to be the same? It's a question (and theory) of strategic balance," Strategic Management Journal, 20, pp. 147-166.

Delmas, M. A. (2002), "The diffusion of environmental management standards in Europe and in the United States: An institutional perspective," Policy Sciences, 35, pp. 91-119.

DiMaggio, P. J. and W. W. Powell (1983), "The iron cage revisited: Institutional isomorphism and collective rationality in organizational fields," American Sociological Review, 48, pp. 147160.

Dooley, R. S. and G. E. Fryxell (1999), ”Are conglomerates less environmentally responsible? An empirical examination of diversification strategy and subsidiary pollution in the U.S. chemical industry," Journal of Business Ethics, 21 (1), pp. 1-14.

Dowell, G., S. L. Hart, and B. Yeung (2000), ”Do corporate global environmental standards create or destroy market value?," Management Science, 46 (8), pp. 1059-1074.

Dowling, J. and J. Pfeffer (1975), "Organizational legitimacy: Social values and organizational behavior," Pacific Sociological Review, 18 (1), pp. 122-136.

Eisenhardt, K. and J. A. Martin (2000), "Dynamic capabilities: what are they?," Strategic Management Journal, 21 (10-11), pp. 1105-1121.

EPA (2002), "The toxics release inventory (TRI) and factors to consider when using TRI data," Report no. 60-F-O2-017, pp. 1-29, Environmental Protection Agency (EPA), Washington DC.

Fombrun, C. J. (1996), "Reputation: Realising value from the corporate image," Harvard Business School Press, Boston, Massachusetts.

Ginsberg, A. (1994), "Minding the competition: From mapping to mastery," Strategic Management Journal, 15, pp. 153-174. 
Golden, B. R. (1992), "The past is the past-Or is it? The use of retrospective accounts as indicators of past strategy," Academy of Management Journal, 35 (4), pp. 848-860.

Grant, R. M. (1991), "The resource-based theory of competitive advantage: Implications for strategy formulation," California Management Review, 23, pp. 291-374.

Hall, B. H. and R. H. Ziedonis (2001), "The patent paradox revisited: An empirical study of patenting in the U.S. semiconductor industry, 1979-95," RAND Journal of Economics, 32 (1), pp. 101-128.

Hart, S. L. (1995), "A natural-resource-based view of the company," Academy of Management Review, 20 (4), pp. 986-1014.

Hart, S. L. and G. Ahuja (1996), "Does it pay to be green? An empirical examination of the relationship between emission reduction and company performance," Business Strategy and the Environment, 5 (1), pp. 30-37.

Haveman, H. (1993), "Follow the leader: Mimetic isomorphism and entry into new markets," Administrative Science Quarterly, 38, pp. 593-627.

Hertwich, E. G., S. F. Mateles, W. S. Pease, and T. E. McKone (2001), "Human toxicity potentials for life-cycle assessment and toxics release inventory risk screening," Environmental Toxicology and Chemistry, 20 (4), pp. 928-939.

Hoffman, A. J. (1997), "From heresy to dogma: An institutional history of corporate environmentalism," New Lexington Press, San Francisco.

Hoffman, A. J. (1999), "Insitutional evolution and change: Environmentalism and the U.S. chemical industry," Academy of Management Journal, 42 (4), pp. 351-371.

Hoffman, A. J. (2000), "Competitive environmental strategy: A guide to the changing business landscape," Island Press, Washington, D.C.

Hoffman, A. J. (2001), "Linking organizational and field-level analyses," Organization \& Environment, 14 (2), pp. 133-252.

Hoffman, A. J. and M. J. Ventresca (2002), "Organizations, policy, and the natural environment," Stanford University Press, Stanford (CA).

Jaffe, A. B. and K. Palmer (1997), "Environmental regulation and innovation: A panel data study," The Review of Economics and Statistics, 79 (4), pp. 610-619.

Jennings, P. D. and P. A. Zandbergen (1995), "Ecologically sustainable organizations: An institutional approach," Academy of Management Review, 20 (4), pp. 1015-1052.

Kassinis, G. and N. Vafeas (2002), "Corporate boards and outside stakeholders as determinants of environmental litigation," Strategic Management Journal, 23 (5), pp. 399-415.

Kassinis, G. and N. Vafeas (2006), "Stakeholder pressures and environmental performance," Academy of Management Journal, 49 (1).

Khanna, M. and L. A. Damon (1999), "EPA's voluntary 33/50 program: Impact on toxic releases and economic performance of companies," Journal of Environmental Economics and Management, 37, pp. 1-25. 
King, A. A. and M. J. Lenox (2000), "Industry self-regulation without sanctions: The chemical industry's responsible care program," Academy of Management Journal, 43 (4), pp. 698-716.

King, A. A. and M. J. Lenox (2002), "Exploring the locus of profitable pollution reduction," Management Science, 48 (2), pp. 289-299.

Klassen, R. D. and C. P. McLaughlin (1996), "The impact of environmental management on company performance," Management Science, 42 (8), pp. 1199-1214.

Klassen, R. D. and D. C. Whybark (1999), "The impact of environmental technologies on manufacturing performance," Academy of Management Journal, 42 (6), pp. 599-615.

Klein, B., R. G. Crawford, and A. A. Alchian (1978), "Vertical integration, appropriate rents, and the competitive contracting process," Journal of Law and Economics, 21 (2), pp. 297-326.

Kondra, A. Z. and C. R. Hinings (1998), "Organizational diversity and change in institutional theory," Organization Studies, 19 (5), pp. 743-767.

Lanjouw, J. O. and A. Mody (1996), "Innovation and the international diffusion of environmentally responsive technology," Research Policy, 25 (4), pp. 549-571.

Lawrence, T. (1999), ”Insitutional strategy,” Journal of Management, 25 (2), pp. 161-188.

Lieberman, M. B. and D. B. Montgomery (1998), "First mover (dis) advantages: Retrospective and link with the resource-based view," Strategic Management Journal, 19 (12), pp. 11111125.

Makadok, R. and J. Barney (2001), "Strategic factor market intelligence: An application of information economics to strategy formulation and competitor intelligence," Management Science, 47 (12), pp. 1621-1638.

Markman, G. D., M. I. Espina, and P. H. Phan (2004), "Patents as surrogates for inimitable and non-Substitutable resources," Journal of Management, 30 (4), pp. 529-544.

Martinez, R. J. and M. T. Dacin (1999), "Efficiency motives and normative forces: Combining transactions costs and institutional logic," Journal of Management, 25 (1), pp. 75-96.

Meyer, A. D. (1982), ”Adapting to environmental jolts," Administrative Science Quarterly, 27, pp. 515-537.

Meyer, J. and B. Rowan (1977), "Institutional organizations: Formal structure as myth and ceremony," American Journal of Sociology, 83, pp. 340-363.

Milstein, M. B., S. L. Hart, and A. S. York (2002), "Coercion breeds variation: The differential impact of isomorphic pressures on environmental strategies," in A. J. Hoffman and M. J. Ventresca (eds.), "Organizations, policy, and the natural environment: Institutional and strategic perspectives,” Stanford, CA: Stanford University Press, pp.151-172.

Moses, D. (1992), "Organizational slack and risk-taking behavior: Tests of product strategy," Journal of Organizational Change Management, 5 (3), pp. 38-54.

Nohria, N. and R. Gulati (1996), "Is slack good or bad for innovation?," Academy of Management Journal, 39 (5), pp. 1245-1264. 
Oliver, C. (1991), "Strategic responses to institutional processes," Academy of Management Review, 16 (1), pp. 145-179.

Oliver, C. (1997), "Sustainable competitive advantage: combining institutional and resourcebased views," Strategic Management Journal, 18 (9), pp. 697-713.

Peteraf, M. A. (1993), "The cornerstones of competitive advantage: A resource-based view," Strategic Management Journal, 14 (3), pp. 179-191.

Pfeffer, J. and G. Salancik (1978), "The external control of organizations: A resource dependence perspective," Harper and Row, New York, NY.

Porter, M. E. and C. van der Linde (1995a), "Green and competitive: Ending the stalemate," Harvard Business Review, 73 (5), pp. 120-134.

Porter, M. E. and C. van der Linde (1995b), "Toward a new conception of the environmentcompetitiveness relationship,” Journal of Economic Perspectives, 9 (4), pp. 97-118.

Porter, M. E. (2004), "Competitive strategy," in B. de Wit and R. Meyer (eds.), "Strategy, process, content, context: An international perspective", Thomson Learning, London, pp.258-262.

Powell, W. W. (1991), "Expanding the scope of institutional analysis," in W. W. Powell and P. J. DiMaggio (eds.), "The new institutionalism in organizational analysis," University of Chicago Press, Chicago, pp.183-203.

Russo, M. V. and P. A. Fouts (1997), "A resource-based perspective on corporate environmental performance and profitability," Academy of Management Journal, 40 (3), pp. 534-559.

Russo, M. V. and N. S. Harrison (2005), "Organizational design and environmental performance: Clues from the electronics industry," Academy of Management Journal, 48 (4), pp. 582-593.

Scott, W. R. (1995), ”Institutions and organizations," Sage, Thousand Oak, CA.

Scott, W. R. (2005), "Institutional theory: Contributing to a theoretical research program," in K. G. Smith and M. A. Hitt (eds.), "Great minds in management: The process of theory development," 0xford University Press, London, pp. 460-485.

Sharfman, M. P., G. Wolf, R. B. Chase, and D. A. Tansik (1988), "Antecedents of organizational slack," Academy of Management Review, 13 (4), pp. 601-614.

Sharma, S. and H. Vredenburg (1998), "Proactive corporate environmental strategy and the development of competitively valuable organizational capabilities," Strategic Management Journal, 19 (8), pp. 729-753.

Sharma, S. (2000), "Managerial interpretations and organizational context as predictors of corporate choice of environmental strategy," Academy of Management Journal, 43 (4), pp. 581-597.

Sherer, P. D. and K. Lee (2002), "Institutional change in large law companies: A resource dependency and institutional perspective," Academy of Management Journal, 43 (1), pp. 102119.

Shrivastava, P. (1995), "The role of corporations in achieving ecological sustainability," Academy of Management Review, 20 (4), pp. 936-960. 
Singh, J. V., D. J. Tucker, and R. J. House (1984), "Organizational legitimacy and the liability of newness," Administrative Science Quarterly, 31, pp. 171-193.

Staw, B. M. and L. D. Epstein (2000), "What bandwagons bring: Effects of popular management techniques on corporate performance, reputation, and CEO pay," Administrative Science Quarterly, 45, pp. 523-556.

Theyel, G. (2000), "Management practices for environmental innovation and performance," International Journal of Operations \& Production Management, 20 (2), pp. 249-266.

Toffel, M. W. and J. D. Marshall (2004), "Improving environmental performance assessment: Comparative analysis of weighting methods used to evaluate chemical release inventories," Journal of Industrial Ecology, 8 (1-2), pp. 143-172.

Trostel, A. O. and M. L. Nichols (1982), "Privately-held and publicly-held companies: A comparison of strategic choices and management processes," Academy of Management Journal, 25 (1), pp. 47-62.

Wernerfelt, B. (1984), "A resource based view of the company," Strategic Management Journal, 5, pp. (171- 180).

Williamson, O. E. (1985), ”The Economic Institutions of Capitalism," The Free Press, New York.

Wu, H. L. (2007), "When does internal governance make companies innovative?," Journal of Business Research.

Ziedonis, R. H. (2004), "Don't fence me in: Fragmented markets for technology and the patent acquisition strategies of companies," Management Science, 50 (6), pp. 804-820. 


\section{Table 1}

Descriptive Statistics and Correlations

\begin{tabular}{lrrrr}
\hline & Mean & St. Dev. & Min. & Max. \\
\hline Patents & 0.24 & 0.98 & 0 & 13 \\
Citations & 1.74 & 3.63 & 0 & 27 \\
Regulatory forces & 0.04 & 0.24 & 0 & 3 \\
Normative forces & $67 \mathrm{E}+6$ & $18 \mathrm{E}+8$ & 0 & $6.53 \mathrm{E}+10$ \\
Size & 33 & 63 & 0.005 & 594 \\
R\&D Expenditures & 446 & 1,026 & 0 & 7,900 \\
Capital Intensity & 644 & 5,261 & 0,01 & 123,234 \\
Working Capital/Sales & 1.79 & 16,06 & -1.78 & 381.9 \\
Revenues/Income & -107 & 1,449 & $-39,372$ & 726 \\
No R\&D & 0.093 & 0.231 & 0 & 1 \\
\hline
\end{tabular}

Notes: Descriptive statistics about citations correspond to the subsample of companies with environmental patents. R\&D expenditures and capital intensity are in thousands of Euros. Size is in thousands of employees. Normative forces are in thousands of pounds.

\section{Table 2}

Negative Binomial Estimations

\begin{tabular}{|c|c|c|c|c|}
\hline \multicolumn{5}{|c|}{ Dependent variable: Environmental innovations } \\
\hline & (1) & (2) & (3) & (4) \\
\hline Size $_{(\mathrm{t})}$ & $0.661^{* * *}$ & $0.413^{* * *}$ & $0.392^{* *}$ & $0.369^{* *}$ \\
\hline$R \& D$ effort $(t)$ & $1.722^{\star \star \star}$ & $1.131^{* * *}$ & 0.588 & 0.614 \\
\hline Capital Intensity (t) & $0.620^{\star \star *}$ & $0.503^{* * *}$ & $0.436^{\star \star *}$ & $0.545^{\star \star *}$ \\
\hline Regulatory forces $(t-2)$ & --- & $1.936^{* * *}$ & $2.608^{* * *}$ & $1.212^{\star *}$ \\
\hline Normative forces $_{(\mathrm{t}-2)}$ & --- & $0.089^{* \star *}$ & 0.007 & 0.050 \\
\hline Org. slack $1_{(\mathrm{t}-2)}$ & --- & --- & 0.124 & --- \\
\hline Org. slak $1_{(\mathrm{t}-2)}{ }^{\star}$ Regulatory forces $(\mathrm{t}-2)$ & --- & --- & $-0.647^{* * *}$ & --- \\
\hline Org. slack $1_{(\mathrm{t}-2)}{ }^{*}$ Normative forces $(\mathrm{t}-2)$ & --- & --- & 0.097 & --- \\
\hline Org. slack2 $2_{(t-2)}$ & --- & --- & --- & 0.001 \\
\hline Org. slack $2_{(\mathrm{t}-2)}{ }^{*}$ Regulatory forces $(\mathrm{t}-2)$ & --- & --- & --- & $-0.013^{* *}$ \\
\hline Org. slack2 $(\mathrm{t}-2)^{*}$ Normative forces $(\mathrm{t}-2)$ & --- & --- & --- & $-0.009^{*}$ \\
\hline No $R \& D_{(t)}$ & 0.511 & 1.386 & 1.620 & 1.123 \\
\hline Sector dummies & Yes & Yes & Yes & Yes \\
\hline Geographical dummies & Yes & Yes & Yes & Yes \\
\hline Year dummies & Yes & Yes & Yes & Yes \\
\hline Constant & $-8.503^{* * *}$ & $-6.021^{* * *}$ & $-5.814^{* * *}$ & $-6.944^{* * *}$ \\
\hline Sample size & 916 & 886 & 810 & 847 \\
\hline Wald Chi2 & $7,354.67$ & $9,601.4$ & $12,712.6$ & $12,012.27$ \\
\hline
\end{tabular}




\section{Table 3}

Negative Binomial Estimations

\begin{tabular}{|c|c|c|}
\hline \multicolumn{3}{|c|}{ Dependent variable: Environmental innovations } \\
\hline & (5) & (6) \\
\hline Size $_{(\mathrm{t})}$ & $0.383^{* \star}$ & $0.442^{\star \star *}$ \\
\hline$R \& D$ intensity (t) & 0.240 & 0.024 \\
\hline Capital intensity $(t)$ & $0.636^{\star \star *}$ & $0.594^{\star *}$ \\
\hline Regulatory forces $(t-2)$ & 0.669 & -6.576 \\
\hline Normative forces $_{(\mathrm{t}-2)}$ & 0.047 & 0.078 \\
\hline$R \& D$ intensity $(t){ }^{*}$ Regulatory forces $(t-2)$ & $2.104^{* \star}$ & $2.844^{\star *}$ \\
\hline$R \& D$ intensity $y_{(t)}{ }^{*}$ Normative forces $(t-2)$ & -0.256 & -0.023 \\
\hline${\text { Capital intensity }(t){ }^{*} \text { Regulatory forces }(t-2)}$ & --- & $1.559^{\star \star}$ \\
\hline Capital intensity $y_{(t)}{ }^{*}$ Normative forces $_{(t-2)}$ & --- & -0.019 \\
\hline No $R \& D_{(t)}$ & 1.094 & 1.303 \\
\hline Sector dummies & Yes & Yes \\
\hline Geographical dummies & Yes & Yes \\
\hline Year dummies & Yes & Yes \\
\hline Constant & $-7.264^{* * *}$ & $-7.394^{* * *}$ \\
\hline Sample size & 886 & 816 \\
\hline Wald Chi2 & $12,616.21$ & $14,644.83$ \\
\hline
\end{tabular}

